\title{
INTEGRATED CONTROL SYSTEM OF THE THERMAL POWER COMPLEX USING THE TENSOR ANALYSIS METHODS
}

Solving the problem of energy consumption reducing in the industry is an urgent task. In turn, to reduce the use of fuel, it is necessary to increase the operation efficiency of areas that consume heat and electricity, which can only be achieved through their maximum coordinated work.

Purpose. To investigate tensor analysis methods in automation systems for controlling the heat and power complex.

Methodology. Methods of comparative analysis, mathematic simulation are used; experimental studies are conducted.

Findings. In the modern automation systems, the formation of a control action uses predicted values obtained from mathematical models and, therefore, the efficiency of the enterprise will depend on the adequacy of the developed mathematical model. If the mathematical model is formulated in a tensor form, then it will describe the process in an adequate way. The paper presents an example of developing a tensor model for the heat and power complex of an enterprise and its use on the example of a block diagram of a control system.

Originality. Substantiation of using tensor analysis methods in the heat and power complex control system consisting of the steam source and consumers is given. This approach allowed us to quickly (by measured data) identify the state of the technological process and to calculate its tensor model, which was later used for the formation of control action.

Practical value. The results of the work allow us to improve conventional automation systems by adding mechanisms, which enable us to simulate a technological process in a control system using a tensor analysis method and generate a control signal.

Keywords: heat and power complex, tensor, radius-vector, projection, deviation, control

Introduction. Coordination of work between technological complexes and devices is of great importance at a modern enterprise.

Each segment of the technological steam production and consumption complex of "steam boiler-turbine-vented steam device" (Fig. 1) has its own local automated control system, which operates the certain clump and the whole processing line. An effort of each part is focused on supporting the device service within the specified operating practice. Besides, all of them form a single integrated technological system. Of great importance are, firstly, coordination of all technological units as a whole and, secondly, realization of a possibility of forming a control action (in case of deviation from the normal functioning of a separate device), which takes into account process adjustments of other devices, which are connected with the control device by internal bondings. This management approach allows you to improve the efficiency of how your company works. So the main task for the industry is finding a solution for losing the power saving problem. This should include the reduction of the plant heat rate in the steam form for technological needs, for which production industrial boilers and TPS spend more than $80-85 \%$ of the total amount of purchased fuel [1]. That is, significant losses of fuel and energy are formed mainly in the area of steam production and its consumption (generator, evaporation station), and, therefore, the primary task of the control system is to reduce them. This can be achieved only through the distinct coordination of work of all the devices of the complex and compliance with the relevant requirements for the construction of automated control systems. It will allow taking the necessary control actions according to the work of a separate device and coordination of its work as a structural unit of the complex by an appearance of deviations and transient processes.

The typical processing line of this complex (Fig. 1) includes a steam generator, steam turbine, and evaporation station. Each line is technically connected with the material and energy flows. This connection causes the appearance of disturbing factors. For example, by the same steam consumption at the inlet and outlet of each section a different technological process will be generated due to different internal steam energy

(c) Sidletskyi V. M., Elperin I. V., 2019 (temperature, pressure). Through the inlet steam conduit, the steam enters the high-pressure section (HPS) of the turbine, where it triggers the first impeller through the guide vanes. After giving a particular part of the energy and pressure for the rotation of the first wheel, the steam enters the low-pressure section (LPS), where it transfers residual power to the rotation of the second wheel, which drives the turbine shaft. After the steam turbine, the exhaust steam, as well as some part of the primary steam from the steam boiler, goes to the pressure reducing desuperheating station (PRDS). Then the steam enters the evaporation station, which is condensed in a condenser after the last frame. Condensate and additional water are fed to the chemical water treatment (CWT) section and then again to the steam boiler.

Analysis of the functioning of the complex (Fig. 1) indicates that the effectiveness of its work will depend on the work of each technological area. That is why each local control system activity (separately) and the activity of the integrated control system will both coordinate the work of local control systems. That is, the control system at the highest level determines the necessary technological mode (for example for minimizing the raw stock and energy commodities losses) within the fixed technological method and forms control actions (change in the technological process) in a way to achieve a given performance but not to unbalance the system by the applied control.

Literature review. The urgency of the task of increasing the efficiency of industrial thermal power plants and heat supply systems of industrial enterprises are given in [2]. The ways of achieving economic efficiency are shown through the use of additional units, namely the use of a thermal circuit for an industrial CHP by applying reduction turbines with production selection for steam transfer (or evaporation) plants and for covering heating loads.

Besides, we should note such an important factor as the use of energy sources in places of their receipt, such as mining and concentrating companies. For example, [3] presents a study to review and develop models for controlling a mining combine. In [4] there is shown a survey aimed at developing adaptive models for controlling conveyor belts and choosing the optimal mode of a combine operation. That means it will be necessary not only to tie up the steam production and con- 


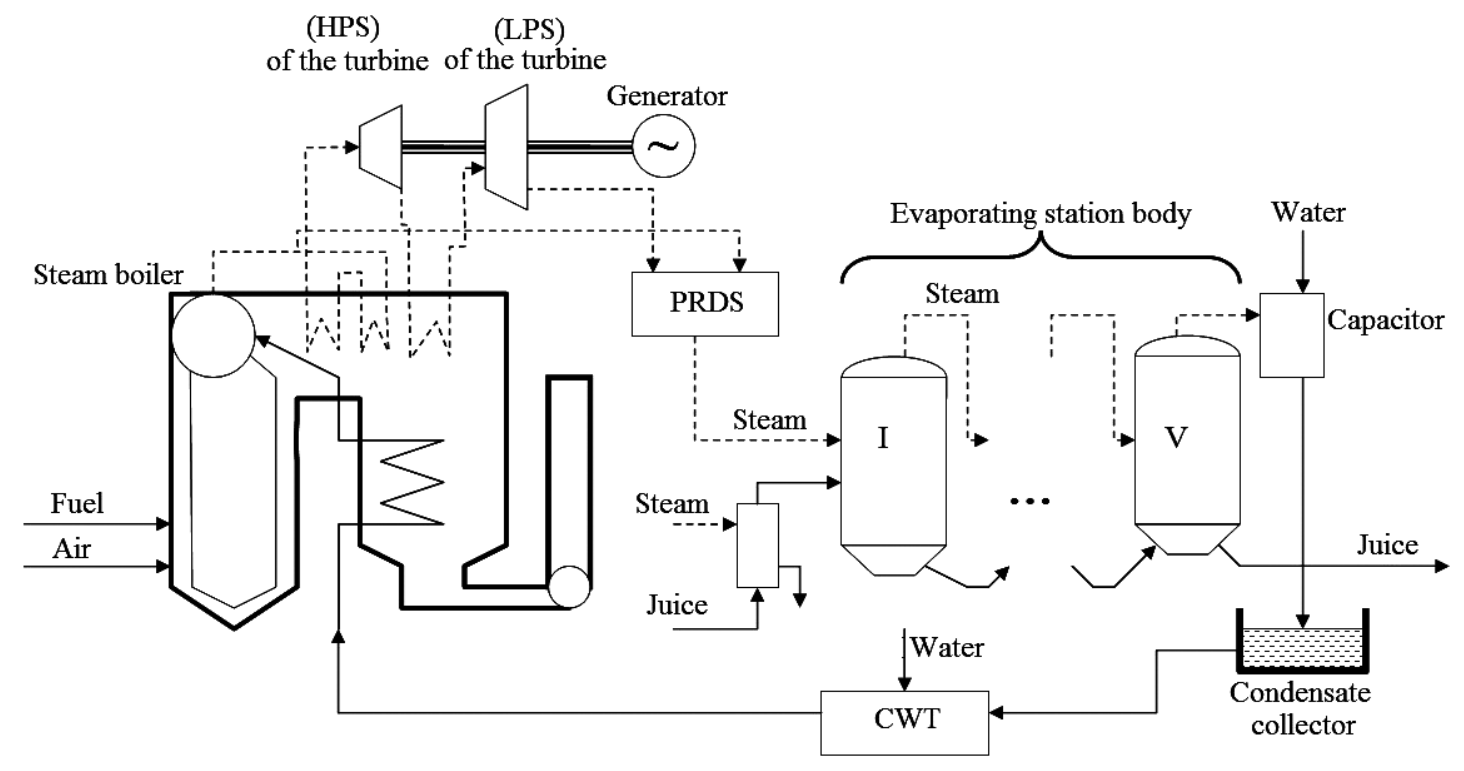

Fig. 1. Simplified scheme of a steam production and consumption complex

sumption complex but also to add a sector to control the extraction of fuel, which will entail obtaining a general model.

An urgent task is the use of models in heat and power process control systems. The work [5] provides an analysis of the current state of modeling various components of district heat supply systems, their advantages and disadvantages, which is necessary for choosing a method for optimization of the workflow.

In [6] another urgent task of the steam production and consumption complex is revealed, which is the compensation of peak loads. It is solved by adding to the heating scheme another steam boiler, which performs the functions of peak load compensation.

In [7] the ways of achieving the efficiency of the complex work by selecting one of three options for the operation of technological equipment are also indicated. These approaches can be implemented only at the stage of developing a new or upgrading an existing complex.

The use of these approaches does not provide for the behavior of the complex in transition processes. It is advisable to use automated control systems to achieve economic indicators.

For example, in [8] the technical-and-economic indexes are already achieved by optimizing the use of metamodeling. A metamodel is used as an analytical and explanatory tool for interpreting the relationship between production costs and revenues from the sale of heat and electricity.

In [9] it is expected to achieve the optimal operation conditions by regulation of the temperature in steam boilers using a predictive model with the Simulink and MATLAB software packages.

In [10] is given the algorithm development for the stabilization and optimal control of boilers program using calculations and determining the optimal load values of each steam generating unit included in running. All calculations were carried out using mathematical models.

Despite a significant amount of research studies, there are still unsolved issues related to the need for a constant recalculation of the coefficients of mathematical models.

The reason for this may involve objective factors associated with changes in carrying out the technological process, and changes in the characteristics of the technical equipment.

Fundamentally, such an approach (system training on time series) cannot be used, for example, during transient processes, at the moments of starting or stopping equipment, changing work conditions of adjacent areas [11].
This, in turn, leads to protracted transient processes, which increases the expenditure of power and material resources. Thus, this study needs refinement.

The task can be attributed to the control signal generating a task for achieving an effective technological mode within the current complex functioning and with restrictions on the transition process in which changes in technical parameters will not extend beyond the regulated values, that is, achieving the specified mode, taking into account the current process.

The solution to this kind of problems was investigated in [12]. But at the same time, the main question remains - finding universal mathematical models of the whole complex, the coefficients of which will be listed by the current state and the mathematical model whose coefficients will be calculated in accordance with the given (ideal) values of technological parameters.

In this case, the control action will be calculated iteratively, according to the model of the current state and the model with the specified technological indicators, which will improve the efficiency of the entire complex work [13].

It is necessary to calculate the controlling effect on the achievement of the indicators of the upper levels (the efficiency of the enterprise work), to consider the indexes of the lower levels (regulated values of the technological parameters). For example, improving the efficiency of the enterprise work (reducing the production cost) by reducing energy consumption (natural gas) while not changing productivity (steam consumption) and performance indexes of adjacent areas - the electrical energy generation and evaporation. That is, to reduce the use of energy resources leaving regulated activity indicators of technological areas where changes in the flow rate, pressure, and steam temperature will bring aggravating factors.

A solution to these problems is to use tensor analysis methods. For example, we recommend such an approach: the use of tensor factorization methods for neural network training, given in [14]. Recently, tensor analysis methods are widely used in solving various problems.

The use of tensors in control systems is a promising direction; in recent years, tensors have been used in many areas, for example for image processing and computer vision [15].

Currently, tensor methods are already used in electrodynamics, in mechanics, in the theory of a gravitational field, in elementary-particle physics, in the study of crystal properties and in differential geometry. In [16] tensor analysis methods were used in the development of a robotic regulator, in aircraft to reduce shock vibration caused by the interaction of tires and the runway. 
Such a wide use of tensor methods in solving modern problems in the processes of analysis and synthesis of systems consists of universality and flexibility. This is explained by the fact that tensors do not change when moving from one coordinate system to another, they allow you to aggregate tasks, and also to decompose tasks by moving from space to a subspace and vice versa.

However, it is necessary to take into account the fact that modern control systems, including the evaporation station automation system, including those built according to international (ISA-95) and European standards (IEC 62264) [17]. Management systems have a hierarchical structure. The automated process control system is at the lower level, and the business process control system is at the highest level.

Based on the analysis, the problem was not considered in this formulation. That is, it is necessary to develop a calculation methodology and principles for using tensor models in the control system of a technological complex with the ability to integrate the developed methodology at each level of the hierarchical structure of modern control systems.

Purpose. The purpose is to synthesize a control system, which will allow forming a control action aimed at achieving specified performance indicators of the technological complex, taking into account the current state of the technical process.

To achieve this goal, it is necessary to solve the following tasks: 1) to analyze the work of the complex sectors to obtain the required parameters that will be considered in the mathematical model; 2) to develop a method for calculating a mathematical model in tensor form; 3) to develop a methodology for calculating the control action for the estimated tensor models; 4) to develop a block diagram of the control system which allows you to find the control action for tensor models.

Calculation of the control action by tensor analysis methods. Analysis of the complex work areas. We assume some simplifications in this work while constructing the entire complex model. For the steam boiler the following parameters were taken into account: gas consumption, water consumption, air consumption, the steam pressure at the outlet, level in the drum. These parameters describe the steam boiler operation in terms of the quantity and quality of the produced steam. They are shown in the parametric scheme in Fig. 2, and their nominal values are given in Table 1 . The following parameters were selected for the steam turbine: input steam flow, steam density, enthalpy of the input pair. For the evaporator station: steam consumption at the inlet, juice consumption at the inlet, secondary steam consumption, consumption of syrup. These parameters are shown in the parametric scheme (Fig. 2) and listed in Table 1, with nominal values and abbreviations. In this case, the simplification (reduced parameter number) affects only the number of calculations, which is primarily related to the peculiarities of tensor modeling. If you need to increase the accuracy of the model and consider the value of other parameters, then they will be added as the vector coordinates (Table 1), and in accordance with the tensor approach, as the coordinates of the radius vector.

Method for calculating a mathematical model in a tensor form. We accept that it is possible to distinguish the vectors of input and output values obtained from the sensors of the technological process (measured and control signals given in Table 1) in the heat and power complex control system of an enterprise for input parameters. It means, as a parameters vector at the system input $\vec{x}=\left(x_{1}, x_{2}, \ldots, x_{n}\right)^{T}$ and a vector of values describing the process flow $\vec{y}=\left(y_{1}, y_{2}, \ldots, y_{m}\right)^{T}$. Therefore, at the first stage, the relationship between $\vec{x}_{\text {, and }} \vec{y}_{\text {, was presented as }}$ a system of linear equations, which in turn allowed us to obtain a dependence as a quadric form

$$
y=f(X)=\sum_{1 \leq j, k \leq n} a_{i j} x_{j} x_{k}=X^{T} A X,
$$

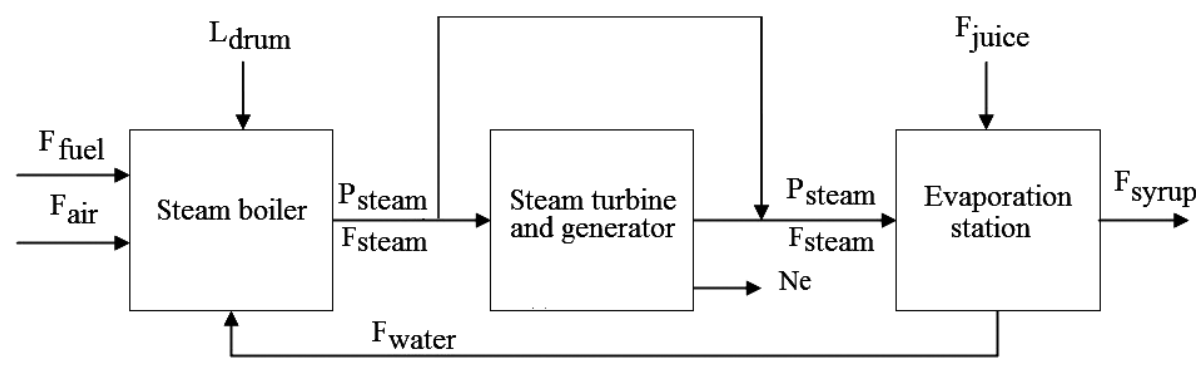

Fig. 2. Simplified parametric of the steam production and consumption complex in the enterprise

Table 1

Heat and power complex characteristics

\begin{tabular}{|c|c|c|c|c|c|c|c|c|c|}
\hline & \multirow{2}{*}{ Parameter } & \multirow{2}{*}{$\begin{array}{c}\text { Unit of } \\
\text { measurement }\end{array}$} & \multirow{2}{*}{$\begin{array}{c}\text { Contracted } \\
\text { notation }\end{array}$} & \multirow{2}{*}{$\begin{array}{c}\text { Vector } \\
\text { component }\end{array}$} & \multicolumn{5}{|c|}{ Parameter value } \\
\hline & & & & & $\min$ & $\max$ & schedule & specified & measured \\
\hline 1 & Gas flow & TPH & F gas & $x_{1}$ & 3.0 & 5.5 & 3.0 & 2.9 & 2.7 \\
\hline 2 & Water flow & TPH & F water & $x_{2}$ & 9.0 & 25.0 & 5.0 & 5.5 & 5.3 \\
\hline 3 & Air flow & TPH & F air & $x_{3}$ & 9.0 & 10.0 & 7.0 & 6.8 & 6.4 \\
\hline 4 & Steam pressure at the outlet & atm & P steam & $x_{4}$ & 6.5 & 30.0 & 9.0 & 9.3 & 8.6 \\
\hline 5 & Level in drum & $\mathrm{mm}$ & L drum & $x_{5}$ & -50.0 & 50.0 & 5.0 & 5.0 & 7.0 \\
\hline 6 & Steam consumption on the turbine & TPH & F steam & $x_{6}$ & 9.0 & 10.0 & 4.0 & 4.0 & 5.0 \\
\hline 7 & Electrical power & $\mathrm{kW}$ & $\mathrm{Ne}$ & $x_{7}$ & 5.0 & 20.0 & 6.0 & 6.1 & 5.7 \\
\hline 8 & Steam consumption at the inlet & TPH & F steam & $x_{8}$ & 6.0 & 10.0 & 7.0 & 6.8 & 7.1 \\
\hline 9 & Juice consumption at the inlet & $\mathrm{m}^{3} / \mathrm{h}$ & F juice & $x_{9}$ & 7.0 & 14.0 & 8.0 & 7.0 & 7.5 \\
\hline 10 & Secondary steam consumption & TPH & F sec. steam & $x_{10}$ & 4.0 & 10.0 & 6.0 & 5.4 & 5.7 \\
\hline 11 & Syrup consumption & $\mathrm{m}^{3} / \mathrm{h}$ & F syrup & $x_{11}$ & 4.0 & 12.0 & 5.0 & 5.2 & 4.3 \\
\hline
\end{tabular}


where $X=\vec{x}, a_{i j}=A$ is a symmetric matrix whose elements are calculated by the formula

$$
a_{i j}=\left\{\begin{array}{ll}
a_{i j} & i=j \\
\frac{1}{2}\left(a_{i j}+a_{j i}\right) & i \neq j
\end{array} .\right.
$$

The columns of matrix $A$ are the components of the vectors for each parameter. In this case, deviations in the system can be found as $\Delta y=A \Delta x$, where $A$ is a linear equation operator. Then the formula with the deviations will look like $y+\Delta y=$ $=A x+A \Delta x$ or $y=A x+B u$, where the control signal can be measured as $B u=I A K x$, and $I$ is diagonal matrix, with nonzero control values diagonally, in case of simultaneous control of all signals. This will be a single diagonal matrix $K$ coefficient responsible for the magnitude of the control signal, the matrix $A$ operator. Matrix elements with components (2) which are found by expression (1) are a metric tensor. To be able to use it in further calculations, it is necessary for vectors to be pairwise orthogonal. To find orthonormal vectors, the Gram-Schmidt orthogonalization algorithm was used.

The resulting transformations for the heat and power complex parameters are presented as a process of changing the coordinate system in Fig. 3.

In Fig. $3 O Y$ axis is a radius vector with controlled parameters of the technological process, tangent to the surface describing the technological process. The $O X$ axis is perpendicular to the $O Y$ axis, it contains the radius-vector of control parameters of the technological process. The $O Z$ axis completes the system, lies on the normal which is a vector product $\vec{r}_{i} \times \vec{r}_{j}$. On this axis $(O Z)$ the radius vector $\vec{r}_{\ell}$ is situated. In the steady state this vector will be equal to the vectors $\vec{r}_{i}$, and $\vec{r}_{j}$. So by setting the axes of the coordinate system, and the magnitudes of the unit vectors of the basis, you can find the resulting value of the radius vector that characterizes the system behavior: $\vec{a}=a_{x} \vec{i}+a_{y} \vec{j}+a_{z} \vec{k}$ where $\vec{i}, \vec{j}, \vec{k}$ are unit vectors.

The method for calculating the control action for tensor models. According to the method described above, the control action was calculated as the difference between the regulated, measured input and output values of the technological process. In our case, while using tensor analysis and system description in the form of vectors, the difference between regulated and specified values will look like the rotation of the system in space. That is, there has been found a local coordinate system with calculated components. It changes position in space, that is, returns to a certain angle, that is $a_{X, Y, Z}=T a_{i, j, z}$, where $T$ is the rotational tensor, calculated from the Euler angles. The found projection involves approximate values of technological parameters in local coordinates, i. e. $\hat{x}=a_{X, Y, Z}$. According to this, the signal for correction can be measured as $x_{\text {koryg }}=A^{T} A \hat{x}$. Thus, the management process is a sequence in which at the first stage we accept that $x_{0} \in X$, and finding a signal for correction is to substitute values into such congruence $x_{1}=A\left(x_{0}\right)$. After that we perform the next step: $x_{2}=A\left(x_{1}\right)$, then the third $x_{3}=A\left(x_{2}\right)$, and so on. The resulting sequence $\left(x_{n}\right)$ tends to the desired element $x$ at $(n \rightarrow \infty)$.

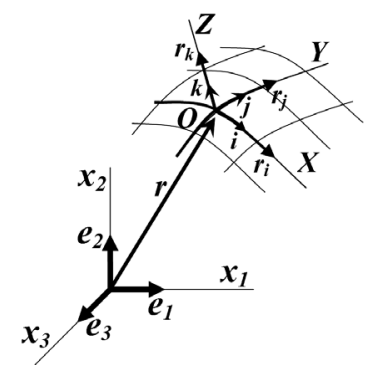

Fig. 3. Control system in local coordinates
Control system schematic structure. Control system schematic structure is presented in Fig. 4. The operation of the system requires many values of technological parameters. The range set consists of the coordinates of the input vectors of the control system: input variables vector $x=f(X)$ is the setpoint vector of control loops in the process control system. Output variables vector $y=f(X)$ is a vector of values of technological parameters, which we get with testing and measuring devices. Regulated parameters vector $y_{\text {reg }}=f(X)$ is a set of parameter values, which must be achieved to comply with the technical and economic indicators of the enterprise, that is the complex of steam production and consumption. Due to the indicated input vectors, we calculate the system state tensors and the regulated tensor $\vec{r}_{i} \cdot \vec{r}_{j}=g_{i j}$.

According to the adjusted values tensor of the technological parameters, there is a vector $\vec{a}_{\text {reg }}$ and its coordinates. For the found vector, we change the coordinate system according to the tensor, which describes the state of the system $a_{X, Y, Z}$. As a result of this, we obtain the coordinate values of the vector in another local basis. The local coordinates help to find the corrective values of technological parameters through the transfer to the global coordinate system.

Calculations and research results. According to Table 1, for the formation of vectors, the values of parameters of the complex of the steam production and consumption are taken: vector of regulated values of technological parameters $\vec{y}_{\text {reg }}=$ $=\{3.0,5.0,7.0,9.0,5.0,4.0,6.0,7.0,8.0,6.0,5.0\} ;$ vector of set values for local regulators of the control system $\vec{x}=\{2.9,5.5,6.8,9.3,5,4,6.1,6.8,7,5.4,5,2\}$; vector of measured (current) values of technological parameters $\vec{y}=\{2.7$, $5.3,6.4,8.6,7.0,5.0,5.7,7.1,7.5,5.7,4.3\}$. Due to these vectors using the expressions $(1,2)$, we measured the quadratic forms, which after orthogonalization allowed obtaining singular vectors for technological parameters in local coordinates of Table 2.

For the values of singular vectors in local coordinates, see the Table. 2. Vectors of input parameters for the control system will be as followed:

- predetermined values vector components

$$
\begin{gathered}
\vec{r}_{i}=15.0 e_{i_{1}}+6.1 e_{i_{2}}+4.9 e_{i_{3}}+4.8 e_{i_{4}}+ \\
+4.5 e_{i_{5}}+4.1 e_{i_{6}}+3.9 e_{i_{7}}+3.7 e_{i_{8}}+3.6 e_{i_{9}}+2.9 e_{i_{10}}+2.1 e_{i_{11}} ;
\end{gathered}
$$

- measured values of the current state of the system vector components

$$
\begin{gathered}
\vec{r}_{j}=15.2 e_{j_{1}}+5.9 e_{j_{2}}+5.2 e_{j_{3}}+5.0 e_{j_{4}}+4.7 e_{j_{5}}+ \\
+4.3 e_{j_{6}}+4.0 e_{j_{7}}+3.8 e_{j_{8}}+3.6 e_{j_{9}}+3.1 e_{j_{10}}+2.0 e_{j_{11}} ;
\end{gathered}
$$

- regulated value vector components

$$
\begin{gathered}
\vec{r}_{k}=15.2 e_{k_{1}}+6.1 e_{k_{2}}+5.4 e_{k_{3}}+4.9 e_{k_{4}}+4.6 e_{k_{5}}+ \\
+4.2 e_{k_{6}}+3.8 e_{k_{7}}+3.5 e_{k_{8}}+3.5 e_{k_{9}}+2.9 e_{k_{10}}+2.2 e_{k_{11}}
\end{gathered} ;
$$

- radius vector of regulated values

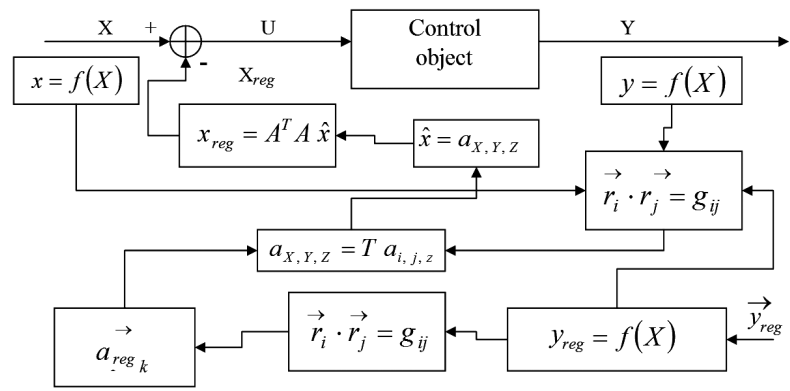

Fig. 4. Control system schematic structure (controlled object) 
Single vectors in local coordinates

\begin{tabular}{|c|c|c|c|c|}
\hline № & $\begin{array}{c}\text { Unit vector for control } \\
\text { variables }\end{array}$ & $\begin{array}{c}\text { Unit vector for measured } \\
\text { variables }\end{array}$ & $\begin{array}{c}\text { Unit vector for prescribed } \\
\text { values }\end{array}$ & $\begin{array}{c}\text { Radius vector } \\
\text { coordinates }\end{array}$ \\
\hline e1 & $0.9865+0.1638 \mathrm{i}$ & $-0.9721+0.2345 \mathrm{i}$ & $1.0000+0.0000 \mathrm{i}$ & $3.0000+0.0000 \mathrm{i}$ \\
\hline e2 & $0.9865-0.1638 \mathrm{i}$ & $-0.9721-0.2345 \mathrm{i}$ & $0.7545+0.6563 \mathrm{i}$ & $2.2636+1.9688 \mathrm{i}$ \\
\hline e3 & $0.3966+0.9180 \mathrm{i}$ & $-0.5369+0.8437 \mathrm{i}$ & $0.7545-0.6563 \mathrm{i}$ & $2.2636-1.9688 \mathrm{i}$ \\
\hline e4 & $0.3966-0.9180 \mathrm{i}$ & $-0.5369-0.8437 \mathrm{i}$ & $0.2910+0.9567 \mathrm{i}$ & $0.8730+2.8702 \mathrm{i}$ \\
\hline e5 & $-1.0000+0.0000 \mathrm{i}$ & $-0.3167+0.9485 \mathrm{i}$ & $0.2910-0.9567 \mathrm{i}$ & $0.8730-2.8702 \mathrm{i}$ \\
\hline e6 & $-0.8534+0.5212 \mathrm{i}$ & $-0.3167-0.9485 \mathrm{i}$ & $-0.2197+0.9756 \mathrm{i}$ & $-0.6591+2.9267 \mathrm{i}$ \\
\hline e7 & $-0.8534-0.5212 \mathrm{i}$ & $0.4400+0.8980 \mathrm{i}$ & $-0.2197-0.9756 \mathrm{i}$ & $-0.6591-2.9267 \mathrm{i}$ \\
\hline e8 & $-0.0895+0.9960 \mathrm{i}$ & $0.4400-0.8980 \mathrm{i}$ & $-0.8777+0.4792 \mathrm{i}$ & $-2.6332+1.4375 \mathrm{i}$ \\
\hline e9 & $-0.0895-0.9960 \mathrm{i}$ & $0.9558+0.2941 \mathrm{i}$ & $-0.8777-0.4792 \mathrm{i}$ & $-2.6332-1.4375 \mathrm{i}$ \\
\hline e10 & $-0.3683+0.9297 \mathrm{i}$ & $0.9558-0.2941 \mathrm{i}$ & $-0.9853+0.1707 \mathrm{i}$ & $-2.9560+0.5120 \mathrm{i}$ \\
\hline e11 & $-0.3683-0.9297 \mathrm{i}$ & $1.0000+0.0000 \mathrm{i}$ & $-0.9853-0.1707 \mathrm{i}$ & $-2.9560-0.5120 \mathrm{i}$ \\
\hline
\end{tabular}

$$
\begin{aligned}
& \vec{a}_{\text {reg } k}=45.7 e_{\text {reg }_{1}}+18.3 e_{\text {regk }_{2}}+16.2 e_{\text {reg }_{3}}+ \\
& +14.8 e_{\text {reg } k_{4}}+13.7 e_{\text {reg } k_{5}}+12.7 e_{\text {reg }_{6}}+11.4 e_{\text {reg } k_{7}}+ \\
& +10.6 e_{\text {reg } k_{8}}+10.6 e_{\text {reg } k_{9}}+8.7 e_{\text {reg } k_{10}}+6.6 e_{\text {reg } k_{11}} \text {. }
\end{aligned}
$$

By the radius of the regulated value vector and by the tensors, calculated from the basis vectors in local coordinates by changing these local coordinates, we find the projection of the radius-vector of regulated values $\vec{a}_{\text {reg } k}$ on the plane $O X Y$

$$
\begin{aligned}
& a_{X, Y, Z}=T a_{i, j, z}=\operatorname{diag}(-2.83,0.78,-0.19, \\
& 0.09,-0.53,-0.70,0.00,0.21,0.37,1.21,14.90) .
\end{aligned}
$$

This projection is the numerical regulated values of the technological process in local coordinates of the current system state basis.

\section{Conclusions.}

1. Forming a control action for the complex performance adjustment ща "steam boiler - turbine - evaporation installation" at the enterprise for the steam production and consumption can only be achieved through efficient operation of the integrated control system. This, in turn, requires the development of an adequate mathematical model.

2. Solving the tasks by using tensor analysis methods allows us to develop a mathematical model in the form that does not depend on the specific values of the process parameters. All dependencies will be linear, and the parameter values will be only used by selecting coordinate axes.

3 . For the tensor analysis methods use in the control system, it is necessary that all the control system parameters should be divided into three vectors: the control vector, the output parameters vector, and the regulated values vector. For calculating the tensors coefficients, it is required to construct quadratic forms from the obtained vectors, which further require the orthogonalization and orthonormal processes to be carried out.

4. Based on the obtained tensors a projection of the desired heat and power complex characteristics on the current state of the system was found for orthonormal vectors. The values found are control actions in local coordinates.

\section{Reference.}

1. Stanheev, K. O., Hrystynko, V. I., Vasylenko, T. P., \& Vasylenko, S. M. (2014). Energy efficient factors for improving the energy efficiency of the sugar industry. Ukrainian Sugar, 2(98), 14-17.
2. Luhtura, F. I., Pyzhykov, A.V., \& Hlestova, O.A. (2014). About ways to improve the thermal efficiency and reliability of industrial CHP. Bulletin of Pryazovian State Technical University. Series: Technical sciences, 36, 88-100.

3. Bublikov, A., Tkachov, V., \& Isakova, M. (2013). Control automation of shearers in term of auger gumming criterion. CRC Press/Balkema - Taylor \& Francis Group: Energy efficiency improvement of geotechnical systems, 137-145. DOI: 10.1201/b16355-19.

4. Tkachov, V., Bublikov, A., \& Gruhler, G. (2015). Automated stabilization of loading capacity of coal shearer screw with controlled cutting drive. In New Developments in Mining Engineering Theoretical and Practical Solutions of Mineral Resources Mining (pp. 465-477). London: Taylor \& Francis Group. DOI: 10.1201/b19901-82.

5. Talebi, B., Mirzaei, P.A., Bastani, A., \& Haghighat, F. (2016). A Review of District Heating Systems: Modeling and Optimization. Frontiers in Built Environment, 2. DOI: 10.3389/ fbuil.2016.00022.

6. Haichao Wang, Risto Lahdelma, Xin Wang, Wenling Jiao, Chuanzhi Zhu, \& Pinghua Zou (2015). Analysis of the location for peak heating in CHP based combined district heating systems Analysis of the location for peak heating in CHP based combined district heating systems. Applied Thermal Engineering, 87, 402-411. 7. Ahmadi, G., Toghraie, D., \& Akbari, O.A. (2018). Technical and environmental analysis of repowering the existing CHP system in a petrochemical plant: A case study. Energy, Elsevier, 159, 937-949.

8. Weinberger, G., \& Moshfegh, B. (2018). Investigating influential techno-economic factors for combined heat and power production using optimization and metamodeling. Applied Energy, Elsevier, 232, 555-571.

9. Soon-Young Choi, Kee-Youn Yoo, Jeong-Bin Lee, Chee Burm Shin, \& Myung-June Park (2010). Mathematical modeling and control of thermal plant in the district heating system of Korea. Applied Thermal Engineering, Elsevier Science B.V., Amsterdam, 30, 2067-2072.

10. Skakovsky, Y., Babkov, A., \& Mandro, E. (2017). Efficiency improvement for sugar plant boiler department work based on boiler units optimal loads distribution, Automation of technological and business processes, 9(3), 24-33.

11. Lapin, M. V., \& Sidletskyi, V. M. (2016). Vykorystannia system nechitkoi lohiky dlia dynamichnoho upravlinnia potuzhnistiu parovykh kotloahrehativ. Naukovi pratsi Natsionalnoho Universytetu Kharchovykh Tekhnolohii, 22(4), 24-31.

12. Teran, P. (2010). On consistency of stationary points of stochastic optimization problems in a Banach space. J. Math. Anal. Appl., 363, 569-578. 
13. Sidletskyy, V. M., Elperin, I. V., \& Polupan, V.V. (2016). Analysis of non-measurement parameters at the level of distributed control for an automated system, objects and complexes of the food industry. Scientific works of the National Food Technologies University, 22(3), 7-15.

14. Lee, N., \& Cichocki, A. (2018). Fundamental tensor operations for large-scale data analysis using tensor network formats. Multidimensional Systems and Signal Processing, 29(3), 921-960.

15. Younas, S., \& Figley, C. (2018). Development, Implementation and Validation of an Automatic Centerline Extraction Algorithm for Complex 3D Objects. Journal of Medical and Biological Engineering, 39(2), 184-204.

16. Kuntanapreeda Suwat, Ronzhin, A., \& Shishlakov, V. (2018). Control of shimmy vibration in aircraft landing gears based on tensor product model transformation and twisting sliding mode algorithm. Abstracts of Papers '18: $13^{\text {th }}$ International Scientific-Technical Conference on Electromechanics and Robotics “Zavalishin's Readings" (pp. 1-6). DOI: 10.2514/2.2744.

17. Sidletskyi, V. M., \& Elperin, I.V. (2016). Expansion of functional possibilities of control systems of technological objects. Naukovyi zhurnal "Tekhnika ta enerhetyka", 256, 113121. Retrieved from http://journals.nubip.edu.ua/index.php/ Tekhnica/article/view/8241.

\section{Інтегрована система керування теплоенергетичним комплексом}

\section{з використанням методів тензорного аналізу}

\section{B. М. Сідлеиький, I. В. Ельперін}

Національний університет харчових технологій, м. Київ, Україна, e-mail: vmsidletskiy@gmail.com; ivelperin@gmail. com

Вирішення проблеми зменшення споживання енергоресурсів у промисловості є актуальною задачею. У свою чергу для зменшення використання палива необхідно підвищувати ефективність роботи ділянок, що споживають теплову та електричну енергію, а це можливо досягти лише за рахунок максимальної узгодженої їх роботи.

Мета. Дослідження методів тензорного аналізу в системах автоматизації керування теплоенергетичним комплексом.

Методика. Застосовані методи порівняльного аналізу, математичного моделювання, виконані експериментальні дослідження.

Результати. У сучасних системах автоматизації при формуванні управляючого діяння використовуються прогнозовані значення, що отримані із математичних моделей, тому, ефективність роботи підприємства буде залежати від адекватності розробленої математичної моделі. Якщо ж математична модель сформульована в тензорній формі, то вона буде описувати процес адекватним чином. У роботі наводиться приклад розробки тензорної моделі для теплоенергетичного комплексу підприємства та іiї використання на прикладі структурної схеми системи управління.

Наукова новизна. Наведено обгрунтоване використання методів тензорного аналізу в системі керування теплоенергетичним комплексом, шо складається із джерела та споживачів пари. Даний підхід дозволив оперативно (за виміряними даними) ідентифікувати стан технологічного процесу й розрахувати його тензорну мо- дель. Знайдену модель у подальшому використали для формування керувального впливу.

Практична значимість. Результати роботи дозволяють удосконалити типові системи автоматизації шляхом доповнення механізмами, шо дозволяють, із використанням методів тензорного аналізу, змоделювати технологічний процес у системі керування та сформувати сигнал керування.

Ключові слова: теплоенергетичний комплекс, тензор, радіус-вектор, проекція, відхилення, управління

\section{Интегрированная система управления теплоэнергетическим комплексом}

\section{с использованием методов тензорного анализа}

\section{В. М. Сидлеикий, И. В. Эльперин}

Национальный университет пищевых технологий, г. Киев, Украина, e-mail: vmsidletskiy@gmail.com; ivelperin@gmail.com

Решение проблемы уменьшения потребления энергоресурсов в промышленности является актуальной задачей. В свою очередь для уменьшения использования топлива необходимо повышать эффективность работы участков, потребляющих тепловую и электрическую энергию, а это возможно достичь только за счет максимальной согласованной их работы.

Цель. Исследование методов тензорного анализа в системах автоматизации управления теплоэнергетического комплекса.

Методика. Применены методы сравнительного анализа, математического моделирования, выполнены экспериментальные исследования.

Результаты. В современных системах автоматизации при формировании управляющего действия используются прогнозируемые значения, полученные с математических моделей, поэтому эффективность работы предприятия будет зависеть от адекватности разработанной математической модели. Если же математическая модель сформулирована в тензорной форме, то она будет описывать процесс адекватным образом. В работе приводится пример разработки тензорной модели для теплоэнергетического комплекса предприятия и ее использование на примере структурной схемы системы управления.

Научная новизна. Приведено обоснование использования методов тензорного анализа в системе управления теплоэнергетического комплекса, состоящего из источника и потребителей пара. Данный подход позволил оперативно (по измеренным данным) идентифицировать состояние технологического процесса и рассчитать его тензорную модель. Найденную модель в дальнейшем использовали для формирования управляющего воздействия.

Практическая значимость. Результаты работы позволяют усовершенствовать обычные системы автоматизации путем дополнения механизмами, позволяющими, с использованием методов тензорного анализа, смоделировать технологический процесс в системе управления и сформировать сигнал управления.

Ключевые слова: теплоэнергетический комплекс, тензор, радиус-вектор, проекция, отклонения, управление

Рекомендовано до публікації докт. техн. наук А. І. Соколенком. Дата надходження рукопису 06.12.18. 